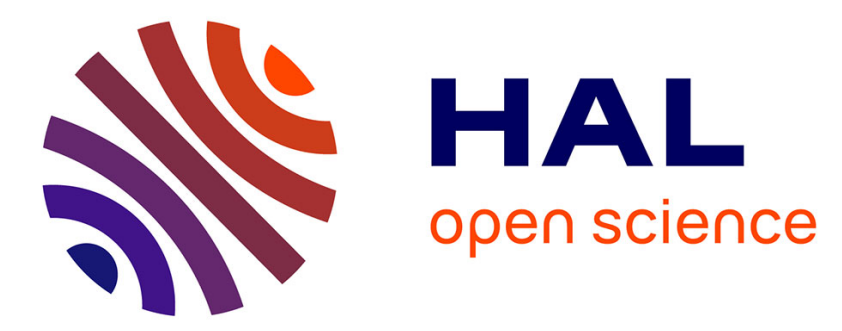

\title{
Capital-labour separation and unequal value-added distribution: repositioning land grabbing in the general movement of contemporary agricultural transformations \\ Hubert Cochet
}

\section{- To cite this version:}

Hubert Cochet. Capital-labour separation and unequal value-added distribution: repositioning land grabbing in the general movement of contemporary agricultural transformations. The Journal of Peasant Studies, 2018, 45 (7), pp.1410-1431. 10.1080/03066150.2017.1311866 . hal-01549060

\author{
HAL Id: hal-01549060 \\ https://hal.science/hal-01549060
}

Submitted on 13 May 2020

HAL is a multi-disciplinary open access archive for the deposit and dissemination of scientific research documents, whether they are published or not. The documents may come from teaching and research institutions in France or abroad, or from public or private research centers.
L'archive ouverte pluridisciplinaire $\mathbf{H A L}$, est destinée au dépôt et à la diffusion de documents scientifiques de niveau recherche, publiés ou non, émanant des établissements d'enseignement et de recherche français ou étrangers, des laboratoires publics ou privés. 


\title{
Capital-Labour Separation and Unequal Value Added Distribution: Repositioning Land Grabbing in the General Movement of Contemporary Agricultural Transformations
}

\author{
Hubert Cochet
}

\begin{abstract}
s
While family agriculture is above all characterised by the non-separation of capital and labour, the recent developments in various forms of production - the land grabbing process in particular - can be analysed from the viewpoint of capital/labour separation. In-depth research conducted in several regions of the world, shows that this process is accompanied by a distribution of value added which is particularly favourable to capital holders but to the detriment of workers, an imbalance which is partly due to the disconnection between salaries and productivity, which is behind the profitability of these projects (the capacity to remunerate invested capitals).
\end{abstract}

\section{Keywords}

Large Scale Project in Agriculture, Land Grabbing, Capital-labour Separation, Distribution of Value added, Comparative Agriculture

\section{Introduction}

We know that the large-scale movement for the acquisition or control of agricultural lands, by public or private actors, increased in scale after the 2007-2008 surges in agricultural prices. This concerns mainly a large movement conducted by private investors, who saw in it an opportunity to make considerable profits while diversifying their business portfolio ${ }^{1}$. These agricultural land acquisition/renting projects in developing countries, have often been presented and justified by their authors as follows: (1) it is imperative to significantly increase agricultural (and energy) production on a global scale to face humanity's growing needs (population growth, progressive generalisation of the consumer model of the countries of the North, predictable exhaustion of fossil energy sources) (World Bank 2007, CAS 2010, for example); (2) there are supposedly close to one billion hectares of good quality land that has not yet been cultivated, is not covered by forest and is as such "available" (IIASA, 2002) ${ }^{2}$; (3) the agricultural sector in developing countries is unable to face this issue; production and productivity are stagnant or do not increase fast enough, due in particular to a crucial lack of investment and access to modern technologies (CAS, 2010; FAO, 2009; UNCTAD, 2009); (4) since States, like the populations concerned (i.e. farmers), do not have the necessary investment capacities, only foreign (public/private) investors from the countries of the North are likely to bring in the necessary capitals. In this sense, foreign investors could replace

\footnotetext{
${ }^{1}$ The governments of certain countries depending very much on the global market for their supply in food and/or agrofuel, have decided to take care of it directly (or via private companies), without going through the global market.

2 According to the FAO and the IIASA, $80 \%$ of them are in Sub-Saharan Africa and Latin America. (Fisher G., Van Velthuizen H et al. 2002).
} 
public development aid, which is on a downward trend, as well as local farmers (CAS 2010, Deininger et al. 2011, FAO 2009); and (5) subject to wide, inexpensive and in the long term stable access to land, foreign investors propose to bring in the capital required for increasing agricultural production. Where the workforce required for the production process can be mostly recruited locally, such investment projects could create jobs and income in rural areas (FAO 2009, Von Braun J. and Meinzen-Dick R. 2009, Deininger et al. 2011, CAS 2010).

But it is important to place the recent expansion of large-scale agricultural investment projects into a wider perspective. Indeed, this phenomenon is not new, contrary to the image given most often by the dominant narrative of this phenomenon (Borras et al., 2012). History is full of examples of powerful land grabbing processes, as illustrated by the colonial conquests of the European powers from the sixteenth to the nineteenth centuries, or by the massive monopolising of lands by the white minority in Southern Africa. More recently, the extensive cattle development process over very large surface areas, to the detriment of the forests of Latin America, went on relentlessly during the entire second half of the twentieth century and the beginning of the twenty-first century, as did the development of palm oil plantations in Indonesia ${ }^{3}$. Moreover, it was during the 1990 s and the 2000 s that national legislations were adapted to the massive input of foreign capitals into the agricultural sector ${ }^{4}$. In fact, the trend whereby foreign investments increased in Sub-Saharan Africa, began well before the 2008 financial crisis, with an important increase taking place just before that, in 2007 (Cotula, et al., 2009). Furthermore, the fairly restrictive definition of the phenomenon ${ }^{5}$ and the emphasis, particularly in Latin America, on the extrangerizacion of land, does not lead to placing this process into a larger scale dynamics (higher historical depth), or to revealing the participation of national companies in the process and therefore differentiation specific to the companies concerned (Borras et al., 2012).

In the contemporary debate on the predictable consequences of large-scale land acquisition/renting processes, rural organisations, NGOs, experts and researchers have pointed out in particular the predictable consequences of these projects, as regards political and social matters (non-transparency of land transactions, conditions for the local governance of land and water resources not being taken sufficiently into account, potential eviction of local populations, appropriation of nature), food security (exporting basic crops, replacing food crops with agrofuels) and environmental risks (deforestation, massive use of synthetic inputs and fossil energy, risks of pollution, diminution of biodiversity) (De Schutter 2009, Technical Committee on "Land and Development" 2010; Songwe and Deininger 2009, Cotula et al. 2009, Borras and Franco 2010, Deininger et al. 2011, McMichael, 2011; Fairhead et al, 2012). Many works have been dedicated to this issue in the past years, as shown by the literature review established by Carlos Oya (2013). Moreover, the debate on the "agrarian issue" and the capital/labour separation has been reactivated, particularly as regards land grabbing in Sub-Saharan Africa, where it appears increasingly clearly that the development of capitalism in agriculture has not been following the "historical" paths of the "classic" agrarian transition (Bernstein, 2009; Oya, 2013; Fairbairn et al, 2014) ${ }^{6}$. This debate also reappeared in

\footnotetext{
324 million hectares of forest were converted into grazing land in the Amazonian Basin between 1990 and 2006, with cattle heads increasing twofold on the continent during the same period (Pacheco and Poccard Chapuis, 2009 quoted by Deininger, 2011); the surface area planted with oil palm went from 2.9 million ha to 6.3 million ha between 1997 and 2007 in Indonesia (Deininger, 2011, see also Li, 2011).

$4 \quad$ For example in Mexico in 1992, in Ethiopia in 1995 and 2002, in Mozambique in 1997, etc.

For example through the Land Matrix Database project (Anseeuw et al., 2012).

${ }^{6}$ In the 1970s, this debate also created much stimulation among the French-speaking scientific community, as shown for example by the works of C. Servolin (1972) on French agriculture or those of the French school of economic anthropology (Meillassoux, 1975) in the case of developing countries.
} 
France, when the development of new farm types seemed to question the exclusivity of the family farm model (Cochet, 2008; Hervieu and Purseigle, 2009; Purseigle and Chouquer, 2012, 2013; Cochet 2017)

Despite this recent explosion, few works have tackled directly the issue concerning the real impact of the capital/labour separation on the actual production process and value added distribution. Yet, we will see that the highly unbalanced nature of distribution between capital and labour, explains mostly why large farms relying on salaried employees sometimes generates considerable profit. They are then considered as highly productive by their promoters, in that they are likely to offer high returns on invested capitals, while their economic efficiency - measured by their capacity to create value added - is not always real.

The aim of this article is to try to reposition the land grabbing process in the general movement of contemporary agricultural transformations, by looking into the creation and distribution processes of value added in capitalist-type farms stemming from recent or old land grabbing processes.

The first part of this article goes back over the general characteristics of family farming, by insisting on the non-separation between capital and labour, considered here as a central element of the productive process, and partly explaining its functioning and performance. In the second part, we will analyse the development of capitalist forms of production in agriculture - and more particularly the recent land grabbing process - from the point of view of capital/labour separation. By illustrating our subject with research results acquired in several regions of the world, we will show in the third part that this process relies on a distribution of value added which is particularly favourable to capital holders, to the detriment of workers. Finally, the last part will show that this imbalance is partly due to the disconnection between salary and productivity. In the conclusion, we will spell out the fact that the profitability of large production units in expansion today (i.e. the capacity of these projects to remunerate invested capitals), is not synonymous with economic and social efficiency, since the latter is understood as the capacity to produce value added, employment and income.

\section{From Family Farming to Capital-Labour Separation}

\section{Family Farm: Historical Development and Organic Link between Capital and Labour}

We know that as early as the end of the nineteenth century, an already very heated debate was raging between on the one hand, the advocates of small family farms, and on the other the promoters of large farms. In Europe in particular, and in the wake of Karl Marx's works, certain authors (e.g. Karl Kautsky in 1900) were foreseeing the end of peasant agriculture and the advent, in agriculture, of capitalist-type productions based on wage earning, and therefore on the separation between capital and labour.

Yet, despite a few major exceptions (forced collectivisation in the former USSR and liquidation of family farming in South Africa, among others), in the end family farms became dominant throughout the second half of the twentieth century on all continents, by progressively replacing very large farms: regression of very large latifundia-type properties in 
the South of Europe and Latin America (agrarian reforms, division through inheritance, selling land in pieces), bankruptcy of colonial plantations in Sub-Saharan Africa and triumph of small planters (in Ivory Coast, for example), dismantling of State farms in many countries of the former Soviet Bloc and partial reappearance of family-type farming... In Western Europe, family farms also laid down the law. Today, the planet counts around 570 million agricultural production units, with 72 per cent of these farming on less than 1 hectare (FAO, 2014). While farm size does not in any way constitute a pertinent definition criterion, it is clear that this proportion illustrates the fact that, worldwide, family farming dominates by far. Moreover, each farm has an average of 0.11 salaried worker (Sourisseau, 2014), which confirms that farm work is mainly carried out by family members worldwide. In addition, it is a segment of commercial family farming that was mainly behind the considerable increase in productivity, as recorded in the agricultural sector in Western Europe and North America since the end of WWII (Mazoyer and Roudart, 2006). Yet, in these regions, the unprecedented increase in the level of capital of farms (and the actual capital owned by farmers) does not make these "capitalist" farms, on the contrary.

The International Year of Family Farming, as proclaimed by the United Nations for 2014, served as a strong argument, calling for this agricultural model to be recognised and rehabilitated in the eyes of the wider public, and to find its central place once again in agricultural policies and investments. A relatively wide consensus has indeed been established concerning the fact that family farming, far from always corresponding to the stereotypes often attributed to it (small farm size, predominance of self-subsistence, poverty etc.), turned out to be efficient as regards producing quality food, managing and conserving complex ecosystems, maintaining or creating jobs, and fighting against poverty (see for example Rosset, 1999; IAASTD, 2009; CSA-HLPE, 2013, Sourisseau, 2014, etc.).

The International Year of Family Farming was also an opportunity to re-examine the definition of family farming. There was wide consensus about dropping size as a criterion to the benefit of criteria characterising the farm operation focused on the family cell, following in fact the precursory works of Tchayanov (1923). The equipment level (and therefore the surface area being farmed) no more than the degree of insertion into trading (resorting to the market to acquire production means, portions of production being consumed and traded) cannot be used as defining criteria (Sourisseau, 2014; FAO, 2014). On the other hand, the fact that most - if not all - the work carried out is supplied by the farmer himself and, if need be, by other members of the family cell, and the fact that the working capital belongs to him in his own right, seem to be the common denominator of all family agricultures. Despite the great diversity that exists today between the different forms of family farming worldwide, this specificity is what unites them and explains their shared economic logic, which has very little to do with profit-seeking in the capitalist sense of the word. Indeed, when labour and capital are owned and used by the same individual, as is the case in family farms, the economic result of the production unit is better measured by farm income which is used to support a family and, if possible, increase its capital. As soon as, on the contrary, the owner of the capital staked in the productive process, no longer or barely (supervision) takes part in the work, and as soon as the latter is carried out by salaried or piece workers, the separation between capital and labour is complete, and running a farm becomes more like running a capitalist business operating in other economic sectors. In this case, the measurement of economic results needs to take into account the separate remuneration of production factors and, in particular, the remuneration of capital (from the perspective of those who provide capital). 
It is not so much about a clear rupture, but more about a continuum of production types between the family and capitalist poles, so that it is often essential to identify (and characterise as such) "employers' farms" between these two poles, in which the family workforce is mobilised together with farm labourers who are hired seasonally or on a full time basis (Dufumier and Bergeret 2002, Sourisseau 2014, Cochet 2015).

Despite Marx's predictions, family-type production in agriculture remained mostly dominant, which did not in any way prevent the capitalist sector from somehow "absorbing" family farming, as shown by the wide debate among the scientific community around this question during the 1970s (see supra and footnote 6).

\section{Recent Expansion of Capitalist Forms in Agriculture: The Different Faces of the Capital- Labour Separation}

Despite the fact that family farms are by far the farm type found the most around the world (supra), certain changes have been seen for a few decades already, in the structural and institutional forms of agricultural productions, changes that often question the family farm. Within the framework of this article, we will not dwell on situations where agro-industries were developed by concluding contracts with producers for their supply, i.e. cotton companies in West Africa, oil palms and/or rubber tree production companies, sugar cane factories, etc. ${ }^{7}$ Although industrial development and the development of capitalist social relations in agriculture are often linked (particularly in the case of the vertical integration of entire networks), here we will limit ourselves to the development of non-family forms of production, at the level of the actual agricultural production process. These new forms of agricultural evolution are extremely varied across the world and with no apparent link between them. As an example, we can mention:

\section{Capitalist Farms with a Salaried Workforce as Forms of Latifundium Modernisation}

Among the latifundia of Southern Europe and Latin America, which are often run very extensively (very little capital and labour per unit area) and in which "pre-capitalist" social relations prevailed, such as share farming or sharecropping, some experienced a modernisation process leading to different forms of capitalist farming and, from then on, based on a salaried workforce, far more capital intensive and sometimes able to generate many jobs: banana production units on the Ecuadorian coast (see the case studies below); irrigated fruit and vegetable producing farms on the coasts of Chile or Peru, greenhousegrown cut flower farms in Ecuador and Colombia as well as, more recently, in Kenya and Ethiopia. Most farms in the hands of Whites in Southern Africa are similar to this category.

On the frontier, we are also witnessing the formation of new and very large farms, relying exclusively on wage earners: yearly crops (soya, sunflower and sorghum) in the lowlands of East Bolivia, oil palm and rubber tree plantations in many regions of Asia, Latin America and Sub-Saharan Africa, large estates of extensive animal farming in the Amazon Basin, new large coffee plantations in the forest high lands of Ethiopia (see the case studies below), among others.

7 This concerns an already ancient form of formalisation by contract, in which the "contract" links many a small producer to a company guaranteeing product marketing (under certain conditions, quantity, quality, regularity, etc.), some of these companies being the direct heirs - after privatisation - to public or parapublic companies that formerly "supervised" certain sectors of production. For a more complete review of the different forms of land use change in relation to land grabbing processes, see Borras, and Franco (2012) 
These are fairly "classic" examples of agricultural transition towards typically capitalist forms of agriculture, built at once on the exclusivity of wage earners. The following examples diverge - sometimes significantly - from this classic pattern.

\section{Privatisation of Former Kolkhozes and Sovkhozes in the Former Soviet Union}

Ukrainian and Russian agriculture is characterised by large farms of several thousand hectares, former Soviet structures (kolkhozes and sovkhozes) that have been privatized. These massive farms lease a large number of plots (small in size, but forming large blocks) from the beneficiaries of the agrarian reform of the 1990s. In addition, new institutional actors are emerging as investors from other sectors, betting on the agricultural potential of the Ukrainian and Russian chernozemic plains: an enormous surface area suitable for large-scale mechanisation and cheaply accessible through leasing. The aim of these foreign and/or Ukrainian/Russian investors is to take control of the large production units privatised in the 1990s by purchasing equipment and leases from former landowners and shareholders (see the case studies below). The conglomeration of farms has led to the creation of vast agroholdings of tens of thousands of hectares, sometimes more than 100000 hectares. In some sectors, control of the entire value chain (upstream and downstream) has led to vertical integration, resulting in significant economies of scale (see for example: Yefimov, 2005; Ioffe and Nefedova, 1998; Visser et al, 2012)

\section{Increasing Reverse Tenancy}

Another scenario appears through reverse tenancy. It concerns contractual relations, as is classic sharecropping, although in this case, it is not the land owner who is in a strong position (as is the case when the sharecropper contributes his workforce and part of the crop expenses to the productive process) but, on the contrary, the "sharecropper" who lays down the law for it is him who brings in the capital required for the production process, and sometimes also privileged access to the market. These new social relations were often developed in contexts where (1) land had been widely distributed within the framework of agrarian reforms in particular, and where (2) the beneficiaries of these reforms did not have sufficient access to production means. For want of widening access to other production factors, fixed and floating capitals in particular, agrarian reforms led to an abundance of agrarian contracts in which the land holder - the lessor - saw his role being limited to the production of fodder, and found himself in a situation of dependence vis-à-vis the "lessee" able to supply the capital required for the production process. Many contemporary situations can be analysed in terms of reverse tenancy (Colin, 2013) ${ }^{8}$. They usually reflect the difficulties encountered by farmers in finding the necessary capital, and their obligation to seek a capital contributor outside the family ${ }^{9}$.

\section{"Agricultural Production Companies" or "Service Companies"}

Another scenario is given by service companies or agricultural entrepreneurs. These companies, with their significant pools of equipment beyond the reach of most farmers, are in

\footnotetext{
$8 \quad$ These reverse tenancy situations can also concern breeding activities as on the cattle breeding frontiers of Mexico (Cochet, Léonard and Tallet, 2010).

9 The former Soviet Bloc situation, as evoked earlier, can also be assimilated to this situation, insofar as the former workers and pensioners of the sovkhozes and kolkhozes, the beneficiaries of land redistribution during the 1990s and who, today, own their plot, cannot cultivate it for lack of capital, and rent it out to a large farm (where sometimes they actually work for a salary).
} 
a position to propose (1) at first a simple paying service for ploughing, harvesting or ensilaging (as agricultural entrepreneurs have been doing for a very long time in Western Europe for example); then (2) inputs in the form of advance payments on crops together with specific crop management sequences (specifications) and marketing guarantees. As the services being proposed become wider, we then begin to shift towards a form of contract which is much closer to integration contracts, or even towards new forms of social relations where farmers become farm workers on their own plots, with the terms and conditions of their remuneration taking or not risk-sharing into account (fixed remuneration or in the form of a portion of the production). Farmers and their plots are then reduced to becoming only an element in a mostly "outsourced" production process, over which farmers no longer have influence as far as taking decisions is concerned ${ }^{10}$.

\section{Examples of New Institutional Arrangement}

The pool de siembra institutional figure, as described by many authors as regards the Southern Cone (for example: Posada and Martínez de Ibarreta, 1998; Grosso, 2010; Albaladejo et al., 2012; Guibert, 2013) has already experienced rapid development in the South American Cone. It relies on the following principle: different actors, each bringing in part of the requested production factors, get together during an agricultural cycle to implement a simplified technical process, based on one or two short cycle crops, as well as a transgenic pack made up of genetically modified organisms, glyphosate and direct seeding. The collective thus constituted rents out the land to former (often family) farmers. In this instance, fixed capital investments are limited to a maximum and everything depends on the supply of services and a temporary or even daily workforce. Here the production process results from a combination of capitals of various origins, brought together during an agricultural campaign and sometimes very highly remunerated, thereby guaranteeing new capitals towards this new institutional form. Beyond the great diversity of possible forms of arrangements between actors, do not pool de siembra constitute a fully "flexible" farming form, very far from the family farming?

In France, where the agricultural sector still relies very much on family farming ${ }^{11}$, we have witnessed for a few decades already the development of different forms of production companies. In this context, the French Rural Economic Centre (CER) network ${ }^{12}$ recently formalised an innovative concept in a document entitled "Flexible Farming" (CER, 2007). According to this document, "flexible farming" results from the implementation of three distinct projects, i.e. proprietary, entrepreneurial and technical projects, which can be run by different people or institutions: first there is the proprietary project which is run by the owner of the farm (who would then be authorised to increase the rent required beyond the current legal limit ${ }^{13}$ ); then there is the agricultural entrepreneur who can accumulate the growth of his activity in an agricultural fund, the value of which includes clients, subcontracting contracts and production rights (...) as well as farming leases; finally, there is the agricultural service contractor who develops a project to supply equipment and labour to agricultural entrepreneurs who, in turn, can offer many variable costs and make the production process

\footnotetext{
10 Many examples of this type of situations are found around the world. For a general idea of these different forms of possible formalisations by contract, see for example: Burnod et al. (2012).

11 The Act of 1946 in particular, on the status of tenant farming and sharecropping, and the blueprint laws of 1960-62 restricting the possible growth of farm sizes to the work capacity of a farmer and his/her spouse.

12 The CER is responsible for keeping farmers' books on their behalf and for offering management advice.

13 The agricultural blueprint law of 2005 introduced the possibility of derestricting rent (through "transferable" lease): a financial investment logic based on farmland then becomes once more possible.
} 
highly flexible. In the eyes of the French CER network, acknowledging the separate identity of the proprietary, entrepreneurial and technical projects makes it possible "to free oneself from the unique family model: capital-family-business", a model denounced by the same authors as belonging in the past. As such, the development of "flexible farming" questions the regulation mechanisms which were established in the 1960s, and which founded the so-called French "structure" policy (Cochet, 2008, 2017).

\section{Current Land Grabbing Process, Expanding on Previous Evolutions}

The examples mentioned above do not reflect all the diversity of current transformations, far from it. Although they are very diverse and without any direct link with one another, these new forms of social relations emerging here and there in the agricultural sector, share a common point: they all contribute to loosening the capital/labour organic link that founded the family farming model. They reveal a progressive - although sometimes brutal - separation between capital and labour: the capital holder no longer, or decreasingly, takes part in the work while the farm worker brings increasingly less or even no capital to the production process.

It seems to us that the current land grabbing process is being construed as an extension - and acceleration - of this evolution, rather than as a new process or a major rupture. The multiple and diverse manifestations of this phenomenon often look like previously mentioned evolutions: reconfiguration of former latifundia into "modern" capitalist farms with salaried workers, development of large capitalist production units replacing former Soviet structures, forms of formalisation by contract via reverse tenancy, service companies taking care of the entire productive process, new institutional forms of production. In the host countries of the main investors, the process is amplified with the creation of large production units, conceived at once on the exclusive basis of agricultural wage earners, replacing existing peasant farming or that could be developed on areas put at the disposal of investors.

\section{Distribution of Value Added in Agricultural Companies: Capital and Labour Shares}

\section{Value Added and its Distribution}

Value added is obtained by deducting from the gross product (home consumption included) the total amount of intermediate consumption used during a production cycle (one year) and, the consumption of fixed capital used in the production process but for which the usage is multi-year (buildings, equipment, perennial plantations) (Fig 1). Value added shows the wealth created during the production process.

Next, distribution of value added is studied between (1) labour compensation (salaries and, in the case of family farming, farm income), (2) cost of capital (interest on any loans, shareholders' revenue), (3) rent paid to landowners and (4) the share paid to the State in taxes and duties linked to the production process ${ }^{14}$. Possible public subsidies may also be taken into account (Fig 1).

The conditions of access to production factors, mostly determined by relations of production, influence the conditions for sharing out value added. In family farming, the biggest share of value

$14 \quad$ Excluding income tax. 
added produced, is generally allocated to the remuneration of the family workforce, in the form of income, except in situations where land access conditions impose a heavy ground rent (sharecropping), or where access to capital, via all sorts of contractual arrangements (reverse tenancy in particular), drastically reduces the share of value added coming to the farmer. In capitalist farms, once the wage bill and social security contributions have been deducted, and once potential ground rents as well as taxes and levies have been paid, what remains of the value added produced constitutes the remuneration of the capital invested in the production process (Fig. 1). A comparative study of value added distribution between the different forms of agriculture, particularly between the different farming structures at work in the same region, makes it possible to highlight, for each one of them, the distribution of value added between capital and labour, and therefore the share of value added dedicated to job creation and income.

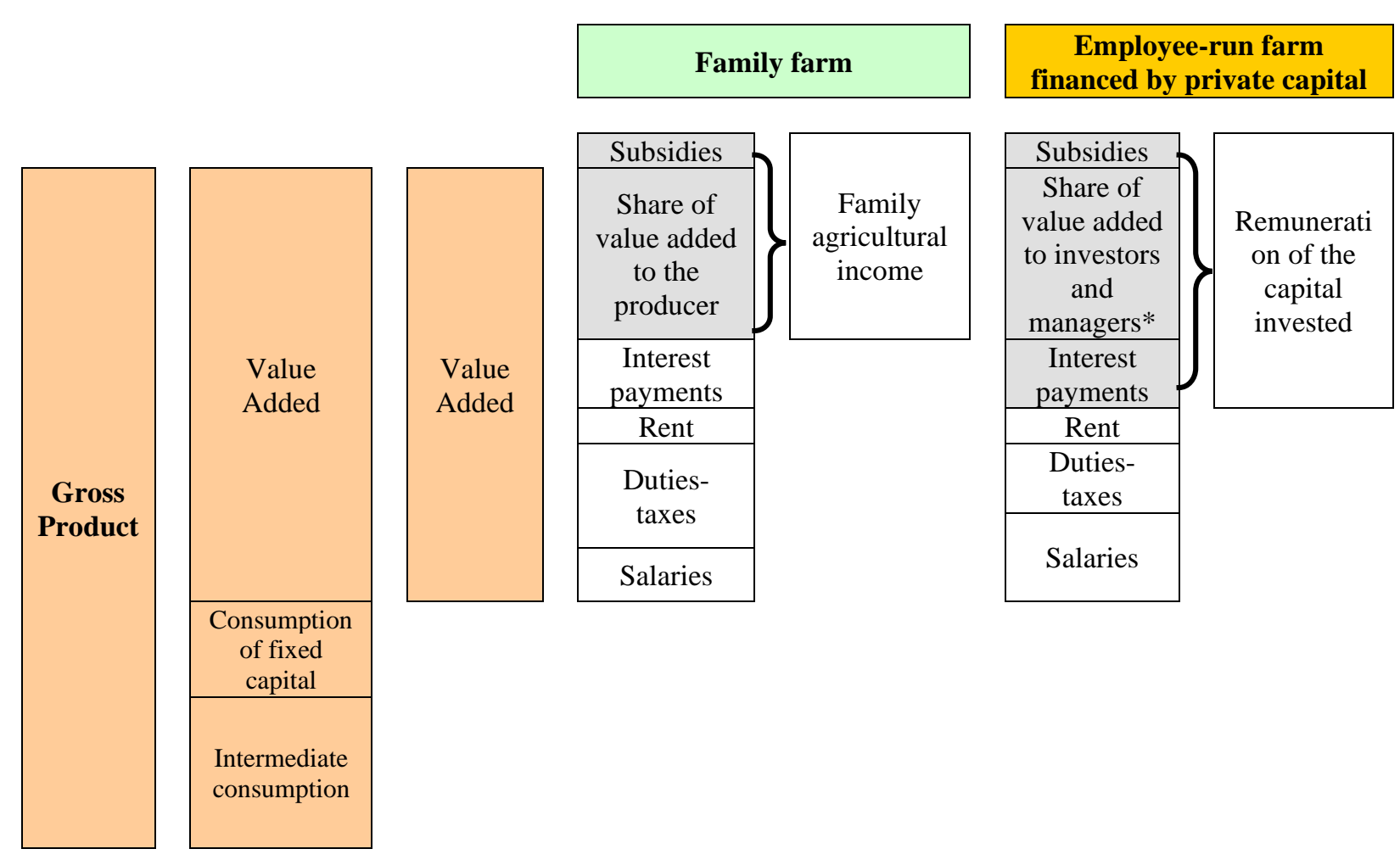

* Only in the case in which the manager is the owner of the farm.

Figure 1: Compared representation of value added distribution in a family farm and in a capitalist farm (Cochet, 2015a)

\section{Evidence from the Ground}

In endeavouring to examine the impact of the capital/labour separation processes on value added distribution, we have examined very different situations resulting either from recent land grabbing dynamics (Ukraine and Ethiopia), or from much older land concentration processes (Ecuador and South Africa). As mentioned above, our hypothesis holds that the current land grabbing process is being construed as an extension - and acceleration - of an already ancient capital/labour separation process, rather than as a new process or major rupture. 
In each case, we have compared different types of farms that are more or less involved in a capital/labour separation process. We then studied the way value added is distributed in order to compare the shares going to labour compensation, capital (investors and financial institutions ${ }^{15}$ ) and other actors (rental payments for land, taxes or duties payed to the state) (See Fig. 1).

The four case studies presented below were conducted under the supervision of the author. In all these case studies, we highlight the modus operandi of each type of operation and the key factors of the value added creation and distribution process.

The following criteria have been $\operatorname{chosen}^{16}$ :

(1) Localised approach allowing for the in-depth study of small agricultural regions, as opposed to the use of possibly unreliable statistics for administrative units too large to account for diversity;

(2) Data collection via face-to-face interviews and surveys of the population concerned, particularly farmers;

(3) An analysis in terms of systems, which implies studying all different types of production units in the study area, and not simply large companies;

(4) Interviews and farm visits which are sufficiently in-depth and frequent so as to collect first-hand, reliable information for calculating the economic indicators of the different types of production units;

(5) A purposive sampling of production units to be studied in detail, in order to comprehend contextual diversity and make comparisons between processes and techno-economic results;

(6) Careful, in-depth analysis of existing social relations and value added distribution mechanisms.

\section{The case of Ecuadorian banana production ${ }^{17}$}

The banana industry has been Ecuador's main source of foreign currency since the 1950s. The country ranks $4^{\text {th }}$ in the production of bananas worldwide, supplies 35 per cent of the world market, and is the world's leading exporter. However, unlike most of its competitors on the international market, Ecuador is unique in that its production structure includes both small and medium-sized producers, as well as larger national and international companies. Despite the tendency of competitors to expand at the expense of smaller farms, the large companies are not the result of recent land grabbing phenomena. The coexistence of farms of very different sizes (from farms of a few hectares to plantations of hundreds or thousands of hectares) makes for interesting comparisons.

Despite the differences observed in terms of planted areas and equipment sophistication, all banana farms rely heavily on manual labour, whether for working in the field or at the processing and packing stations where the majority of tasks is not mechanised. Thus, the difference in the number of jobs per unit area is limited. Little more than one employee/ha is needed on small family farms (1.1 to 1.2) and only 0.69 employee/ha on larger, well-equipped

\footnotetext{
15 This share includes the remuneration of managerial work in case the owner / investor himself oversees operations (conducts managerial tasks).

$16 \quad$ For a detailed examination of this methodology, see Cochet, 2015a.

17 Case study conducted within the framework of a PhD carried out by Dario Cepeda between 2004 and 2008 under the supervision of the author (see also Cepeda, 2009 and Cepeda and Cochet, 2012).
} 
farms (Cepeda, 2009). Considering the differences observed in yields and packing station efficiency, it is possible to highlight more substantial gaps in terms of production of banana boxes per worker (a gap of 1 to 3). Once again, it is evident that the amount of manual tasks required in the production process is what keeps these differences minimal. After adjusting for production costs, differences in labour productivity are somewhat less pronounced ${ }^{18}$.

While the gap in productivity remains modest between small and large farms, it becomes significant when it comes to income. Income differences are directly related to land concentration and production means, and to the dramatic increase in the share of value added allocated to managers and investors (the owner or shareholders) as the size of the farm increases (Table 1). While this share is nil or extremely low for family farms of a few hectares, and for slightly larger manager-run farms (up to ten hectares), value added rises from 15 to 30 per cent for larger manager-run farms and increases to 45 per cent for very large employee-run farms financed by private capital.

Table 1: Share of Value Added in Different Types of Banana Plantations in Ecuador (per cent)

\begin{tabular}{|l|c|c|c|}
\hline \multicolumn{1}{|c|}{ Types of banana plantations } & $\begin{array}{c}\text { Share of Value } \\
\text { Added dedicated } \\
\text { to labour } \\
\text { compensation }\end{array}$ & $\begin{array}{c}\text { Share of } \\
\text { Value Added } \\
\text { dedicated to } \\
\text { remuneration } \\
\text { of capital }\end{array}$ & $\begin{array}{c}\text { Share of Valu } \\
\text { Added } \\
\text { dedicated to } \\
\text { Others (rent, } \\
\text { tax, etc.) }\end{array}$ \\
\hline $\begin{array}{l}\text { A. } \text { Small family plantations (3-5 ha), heirs of the agrarian } \\
\text { reform process and colonisation of the 1960-70s, landlocked } \\
\text { region, difficult access to water for irrigation, no fixed marke } \\
\text { contract. }\end{array}$ & 99 & 0 & 0 \\
\hline $\begin{array}{l}\text { B. } \text { Small manager-run plantations (8-10 ha) emerging from } \\
\text { the division of former banana plantations or formed in the } \\
\begin{array}{l}\text { 1990s, better situated than Type A, and usually having a mor } \\
\text { or less secured contract, irrigated by flooding. }\end{array}\end{array}$ & 100 & 0 & 0 \\
\hline $\begin{array}{l}\text { C. Average-sized manager-run plantations (12-20 ha); direct } \\
\text { contract obtained via export company. }\end{array}$ & 85 & 15 & 0 \\
\hline $\begin{array}{l}\text { D. } \text { Large manager-run plantations (20-50 ha) originating from } \\
\text { the } \text { haciendas of the first half of the 20 } \\
\text { sub-leaf spray, direct contract. }\end{array}$ & 70 & 30 & 0 \\
\hline $\begin{array}{l}\text { E. } \text { Very large employee-run plantations (80-250 ha) financed } \\
\text { by private capital, heirs of the large estates of the early 20 } \\
\text { century, located near transportation routes, direct contract, } \\
\text { irrigation by sub-leaf spray, truck fleet (agroholding). }\end{array}$ & 55 & 45 & 0 \\
\hline
\end{tabular}

Source: H. Cochet according to Cepeda (2009) and Cepeda and Cochet (2012)

\section{The Case of Coffee Production in Ethiopia ${ }^{19}$}

The forest region of South-West Ethiopia, the cradle of Arabica coffee, is characterised by the predominance of small family farms (a few hectares) growing coffee on small surface areas,

18 Key factors underlying productivity differences are as follows: the bargaining power to have a guaranteed contract with export companies and therefore higher prices; the investment in an efficient packing station operating 5 days out of 7 with much lower unit costs (per banana crate); and investment in adequate transportation (trucks) to ensure the independent delivery of product to port (Cepeda and Cochet, 2012)

19 Case study conducted within the framework of a PhD carried out by Samir El Ouaamari between 2008 and 2012 under the supervision of the author. 
and annual food crops by animal traction and gathering activities in forest environments ("wild" honey, Ethiopian cardamom and various materials) (El Ouaamari, 2013).

More recently, and partly because of a national proactive policy advocating the development of coffee growing and the relative specialisation of farmers in this production, other larger forms of production units were developed, calling increasingly on a salaried workforce, hired permanently or paid on a daily basis, or sometimes at piece rates. These new plantations were established as part of large concessions allocated by the public authorities, within the framework of the recent Ethiopian economic policy requiring to open up to large private agricultural investments. While the Ethiopian government's development strategy relied up until recently on the central role supposedly played by small family farming, today it is focusing on large-scale private investment (Lavers, 2012). Currently, in South-West Ethiopia, those who have benefitted the most from the wave of forest concessions with a view to establishing large coffee plantations, are national investors, especially since the middle of the 2000s (El Ouaamari, op cit)

Table $n^{\circ} 2$ shows three types of coffee production units, analysed in detail by Samir El Ouaamari. Here again we find that the value added created is mostly dedicated to the remuneration of the owner-manager (type 1) and capitals of the company (types 2 and 3). Moreover, the more the company increases in size, the more the distributed share becomes hegemonic, going from about 70 per cent for production units of a few dozen hectares, to 85 per cent for companies emanating directly from investors' hosting policies.

\section{Table 2: Distribution of Value Added in Different Types of Coffee Farms in South-West Ethiopia (per cent)}

\begin{tabular}{|c|c|c|c|}
\hline Type of farm & $\begin{array}{l}\text { Share of Value } \\
\text { Added dedicated } \\
\text { to labour } \\
\text { compensation }\end{array}$ & $\begin{array}{l}\text { Share of Value } \\
\text { Added dedicated } \\
\text { to remuneration } \\
\text { of capital* }\end{array}$ & $\begin{array}{l}\text { Share of Value } \\
\text { Added dedicated to } \\
\text { Others (rent, tax, } \\
\text { etc.) }\end{array}$ \\
\hline $\begin{array}{l}\text { 1. Family business farms of } 8-12 \text { hectares of which } 4-6 \text { ha } \\
\text { with yearly crops by animal traction }(2 \text { complete plough and } \\
\text { yoke sets) and } 4-6 \text { ha in coffee; } 3 \text { to } 5 \text { salaried workers. }\end{array}$ & 27 & 73 & 0 \\
\hline $\begin{array}{l}\text { 2. Capitalist farms of } 19-26 \text { hectares of which } 9 \text { to } 12 \text { with } \\
\text { yearly crops with tillage by animal traction ( } 4 \text { complete } \\
\text { plough and yoke sets) and } 10-14 \text { ha of coffee and fruit } \\
\text { plantations, } 12-16 \text { salaried workers. }\end{array}$ & 19 & 69 & 0 \\
\hline $\begin{array}{l}\text { 3. Capitalist farms held by investors benefitting from forest } \\
\text { concessions. Agro-forestry with coffee; hundreds of } \\
\text { hectares; } 15 \text { full-time salaried workers }+400 \text { daily workers } \\
\text { each working } 150 \text { days on average. }\end{array}$ & 15 & 85 & 0 \\
\hline
\end{tabular}

Source: El Ouaamari, 2013

* This share includes the remuneration of managerial work in case the owner / investor himself oversees operations (conducts managerial tasks)

\section{The Case of Ukraine ${ }^{20}$}

If we only consider the large farm part of this dualistic agriculture, this type of farming is characterised by large-scale farms (several thousands of hectares), a reduced salaried workforce and powerful equipment. It is specialised in crop productions which are intended partly for the international market.

20 Research was conducted in 2009 and 2010 in three Oblasts (regions) of the Ukrainian Republic: Jytomyr, Mykolaïv and Kirovograd. 
The distribution of value added is increasingly beneficial to capital: the share that goes to wages has declined, land is cheap, and the amount being paid out to shareholders has increased. Table 3 exemplifies the move from large, recently privatised former Soviet structures in mixed farming operations with multiple crops and livestock (type 1), to the more recent agroholdings with their tens of thousands of hectares (type 4). The table reveals a decrease in value added going to labour compensation, from 38 per cent to just 3 per cent. The share allocated to investors has increased from 54 to 89 per cent.

\section{Table 3: Distribution of Value Added in the Different Types of Large Farms in Ukraine (per cent)}

\begin{tabular}{|c|c|c|c|}
\hline Type of farm & $\begin{array}{l}\text { Share of } \\
\text { Value Added } \\
\text { dedicated to } \\
\text { labour } \\
\text { compensation }\end{array}$ & $\begin{array}{l}\text { Share of Value } \\
\text { Added } \\
\text { dedicated to } \\
\text { remuneration } \\
\text { of capital* } \\
\end{array}$ & $\begin{array}{l}\text { Share of Value } \\
\text { Added dedicatec } \\
\text { to } \\
\text { Others (rent, } \\
\text { tax, etc.) } \\
\end{array}$ \\
\hline $\begin{array}{l}\text { 1. Mixed cropping and livestock operations of the privatized } \\
\text { former Soviet structures: } 2000 \text { ha of barley, wheat, oats, } \\
\text { rapeseed, soybean and sunflower, and some corn and } \\
\text { temporary pasture land, } 100 \text { dairy cows for } 2200 \text { litres, } 80 \\
\text { employees, and partly used heterogeneous equipment. }\end{array}$ & 38 & 54 & 8 \\
\hline $\begin{array}{l}\text { 2. Farms specialising in cereals and oil and protein seed } \\
\text { crops: } 500 \text { to } 3000 \text { ha of barley, wheat, oats, rapeseed, } \\
\text { soybean and sunflower, minimum tillage, precision seed } \\
\text { drills, new and imported high capacity equipment. Economic } \\
\text { performance given for } 1000 \text { ha ( } 11 \text { employees). }\end{array}$ & 19 & 69 & 12 \\
\hline $\begin{array}{l}\text { 3. Agroholdings specialising in large-scale farming: } 5000- \\
30000 \text { ha. Results for one of the agro holdings: } 5000 \text { ha of } \\
\text { barley, wheat, oats, rapeseed, soybean and sunflower, new } \\
\text { and imported equipment, } 33 \text { employees. }\end{array}$ & 10 & 79 & 11 \\
\hline $\begin{array}{l}\text { 4. Agribusinesses specialising in large-scale farming: } \\
>20000 \text { ha rented (straw and reserve land), powerful new } \\
\text { and imported equipment. Shareholders (number N/A), } 210 \\
\text { employees working the equivalent to full time (for } 20000 \\
\text { ha). }\end{array}$ & 3 & 89 & 8 \\
\hline
\end{tabular}

Source: H. Cochet, based on research by C. Jaubertie (type 1, 2 and 3; 2009) and Randimbivololona and Sanchez (type 4 ; 2010), under our supervision.

* This share includes the remuneration of managerial work in case the owner / investor himself oversees operations (conducts managerial tasks)

In some agroholdings of over 20,000 ha specialised in cereals and pulses for the global market, the distribution of value added appears to be particularly unequal. The profitability of large farms is guaranteed by reducing as much as possible the share of value added for workers' compensation. In addition, duties/taxes and rents paid to landowners accounted for only 1 and 7 per cent respectively of the net value added. As such, cost-cutting and the competitiveness acquired on the global market result far more from value added distribution, to the almost exclusive benefit of the capital, rather than from a process for increasing yield and productivity per worker ${ }^{21}$.

\section{The case of South Africa:}

\footnotetext{
${ }^{21}$ As mentioned previously, the control of the entire value chain (upstream and downstream) has led to vertical integration, resulting in significant economies of scale, e.g. for purchasing farm inputs with negotiated prices due to significant volumes.
} 
The current agricultural situation in South Africa does not in any way result from a recent land grabbing process, but from an old movement for the complete dispossession of farmers of African origin. This situation constitutes an almost complete example of separation between capital and labour in agriculture, and clearly illustrates the possible result of processes - ongoing in many regions of the world - for the development of capitalist forms of production in agriculture. That is why we feel that it is of interest to show the way value added is shared between capital and labour in farms stemming from this vast land grabbing process, which are still in the hands of the white minority today.

Despite the shift of government support towards "historically disadvantaged" sectors, the research conducted from 2009 to 2012 in this country (Cochet et al., 2015), suggests that these changes did not actually threaten the commercial profitability of farms. Besides the inherent efficiency of some of these production systems in terms of value added creation, the main reasons for high profitability levels are the very low wages - well below labour productivity - and a distribution of value added that gives capital and farm owners more than their due.

The following examples show the distribution of value added for a small number of specific situations, and the resulting imbalance between how labour and capital are remunerated (Table 4).

- In the irrigated area around Jacobsdal (Free State), the rise in productivity due to farmers' acquisition of powerful equipment, has had a significantly negative effect on employment. On irrigated grain farms, manual jobs have practically disappeared and only a small number of salaried workers remain, usually as farm machine operators. Only about $9 \%$ of the net value added is allocated to worker wages, with 80 per cent going to the entrepreneur's salary and returns on family capital invested in the business (Table 4, [1]).

- Fruit-tree farming is still a fairly labour-intensive sector, so one might expect wages and salary to account for an equally sizeable share of value added. But is this so? At Kiepersol (Municipality of Mbombela, Mpumalanga Province), for example, a closer look at irrigated banana plantations shows that only 17 per cent of value added goes to wages and salaries, even though the production process is still largely based on manual labour (about 1 worker/hectare) (Table 4, [2]) .

- On the large family citrus farms of the Kat River Valley (Eastern Cape), which employ from 10 to 30 agricultural workers along with dozens of seasonal workers for the harvest, value added distribution reserves 30 per cent for the labour force, with the remainder going to the manager's salary and remuneration of capital invested in the farm (Table 4, [3]).

- In the Brits area (northwest of Pretoria), large holdings (70-150 irrigated hectares) specialise in market garden production, selling their produce under contract to supermarket chains in the Johannesburg/Pretoria metropolitan area. These farms employ from 35 to 75 permanent workers who are aided by 20 to 45 temporary workers during the harvest season. Here again, one might expect a significant share of value added to be devoted to remuneration. Yet, only 9 per cent of net value added goes to wages and salaries, while 88 per cent goes to pay for the manager's salary and return on capital (Table 4, [4]).

\section{Table 4: Distribution of Value Added in the Different Types of Large Farms in South Africa (per cent)}




\begin{tabular}{|l|c|c|c|}
\hline Farm Type & $\begin{array}{c}\text { Share of } \\
\text { Value Added } \\
\text { dedicated to } \\
\text { labour } \\
\text { compensation }\end{array}$ & $\begin{array}{c}\text { Share of Value } \\
\text { Added } \\
\text { dedicated to } \\
\text { remuneration } \\
\text { of capital* }\end{array}$ & $\begin{array}{c}\text { Share of Value } \\
\text { Added dedicated } \\
\text { to } \\
\text { Others (rent, } \\
\text { tax, etc.) }\end{array}$ \\
\hline $\begin{array}{l}\text { [1] Large-scale moto-mechanised cultivation } \\
\text { under irrigation (Jacobsdal, Free State); 100- } \\
\text { 150 ha; GMO maize/winter cereals; 2 } \\
\text { cycles/year; 1 family labourer, 4 permanent } \\
\text { workers. }\end{array}$ & $\mathbf{9}$ & $\mathbf{8 0}$ & $\mathbf{1 1}$ \\
\hline $\begin{array}{l}\text { [2] Irrigated tree cultivation; Banana-fruit } \\
\text { (Hazyview, Mpumalanga); 25-100 ha; 20-90 } \\
\text { permanent salaried workers. }\end{array}$ & $\mathbf{1 7}$ & $\mathbf{8 3}$ & $\mathbf{0}$ \\
\hline $\begin{array}{l}\text { [3] Irrigated tree cultivation; Citrus (Kat River } \\
\text { Valley, Eastern Cape); 40-100 ha; 10-30 } \\
\text { permanent + seasonal salaried workers for } \\
\text { harvesting. }\end{array}$ & $\mathbf{3 0}$ & & \\
\hline $\begin{array}{l}\text { [4] Open country irrigated market garden } \\
\text { (Brits, North West Province); under contracts } \\
\text { with supermarkets; 70-150 ha; 35-75 workers + } \\
\text { 20-40 seasonal workers. }\end{array}$ & $\mathbf{9}$ & $\mathbf{7 0}$ & $\mathbf{0}$ \\
\hline
\end{tabular}

Source: Cochet et al., 2015

* As mentioned previously, this share includes the remuneration of managerial work in case the owner / investor himself oversees operations (conducts managerial tasks)

\section{Salary-Productivity Disconnection}

Although at this stage, any generalisation seems out of the question as long as this type of research has not been repeated in more regions, it appears that the more the size of the production unit increases, the more, first of all, salaried work increases to the point of constituting, in the end, the entire work being supplied, and the more, secondly, the share of value added dedicated to remunerating labour decreases in favour of that dedicated to remunerating capital. We also find that this distribution, which is increasingly disadvantageous to labour, is not the only result of an increase in a capital that has been mobilised in the productive process and an increase in labour productivity, but is also the result of a process of disconnection between salaries and productivity ${ }^{22}$.

In the Ukrainian agroholdings specialised in the production of cereals and benefiting from powerful equipment, the value added going to labour is extremely low, i.e. always less than $10 \%$ (Table 3). The same applies to the cereal farms of South Africa where value added represents 9\% (Table 4, [Type 1]). Despite the fact that mechanisation leads to a considerable increase in labour productivity, the share of value added dedicated to their remuneration remains highly minimal: the share of the tractor driver is around 10 times less than the value added generated by his work.

In less mechanised production systems where the production process still relies mainly on manual labour, one would expect the share of value added dedicated to labour to be much more significant. But this is not the case. In the large coffee plantations of South-West Ethiopia (Table 2), where the production process remains entirely manual, value added barely reaches 15 per cent. In irrigated tree cultivation in South Africa, the share of value added dedicated to labour represents only 17 to $30 \%$

\footnotetext{
${ }^{22}$ A tendency which has also been observed in the industrial sector of the countries of the North where, despite significant productivity gains, the share of value added intended for shareholders is maximised to the detriment of that dedicated to labour remuneration (OECD, 2012).
} 
(Table 4). The value added going to labour in the irrigated market garden of the Brits Region (North West Province) remains extremely low, (9\%, see Table 4). It is more considerable in the large banana plantations of the Ecuadorian coast, where labour is also essentially manual, whether in the fields or at the packing station. Yet, 45 per cent of the value added is dedicated to remunerating capital (Table 1).

Following recent or old eviction and land concentration processes, local production systems which are endowed with little capital and are little productive per work unit ${ }^{23}$, are often replaced with larger and better equipped companies often characterised by much higher labour productivity. But the salaries paid to the local workforce - that often comes from the same rural families - remain mainly in line with the very low productivity and remuneration levels of the least productive local farms. What emerges is a complete disconnection between salaries and productivity, to the great advantage of the companies in place: "the wages of the unqualified labour force are established on a level barely above the cost of reproducing labour power - a level close to the threshold of survival for poor peasant agriculture" (Mazoyer and Roudart, 2006: p. 443).

Research works conducted in South Africa offer a particularly striking illustration of this process. Although low labour costs have not always prompted white farmers to invest in productivity increase at the same pace as farmers in Western Europe or other former European colonies, productivity gap between these holdings and the remnants of black agriculture is huge. White farms have productivity levels that are 100 to 300 times higher (Cochet et al., 2015). In agricultural systems where many seasonal or day workers are hired, it is interesting to compare the value added per day of work (daily productivity) to the daily wage. Figure 2 gives the example of 14 different production systems in the Hazyview area studied in detail by Regourd (Cochet et al., 2015). Daily productivity ranges from R50 for production system $\mathrm{n}^{\circ} 10$ (one hectare of market gardening during the rainy season with a single crop per year) to R650 for production system $\mathrm{n}^{\circ} 6$ (irrigated macadamia nut plantation), i.e. a ratio of 1:13. In the labour-intensive production systems of the New Forest irrigated area (former KaNgwane Bantustan), the value added per day of work is very low, even lower than the minimum daily wage (R57). On the other hand, for most of the other production systems shown in Figure 2, daily work productivity is much higher than the wages, which are sometimes completely unrelated to the work's value added. In some production systems, the "return" on an employee's day of work, whether that employee is permanent, seasonal or daily, is twelve times higher than what he or she costs the employer.

\footnotetext{
23 This does not prevent them in any way from often being characterised by high value added production
} per unit area. 


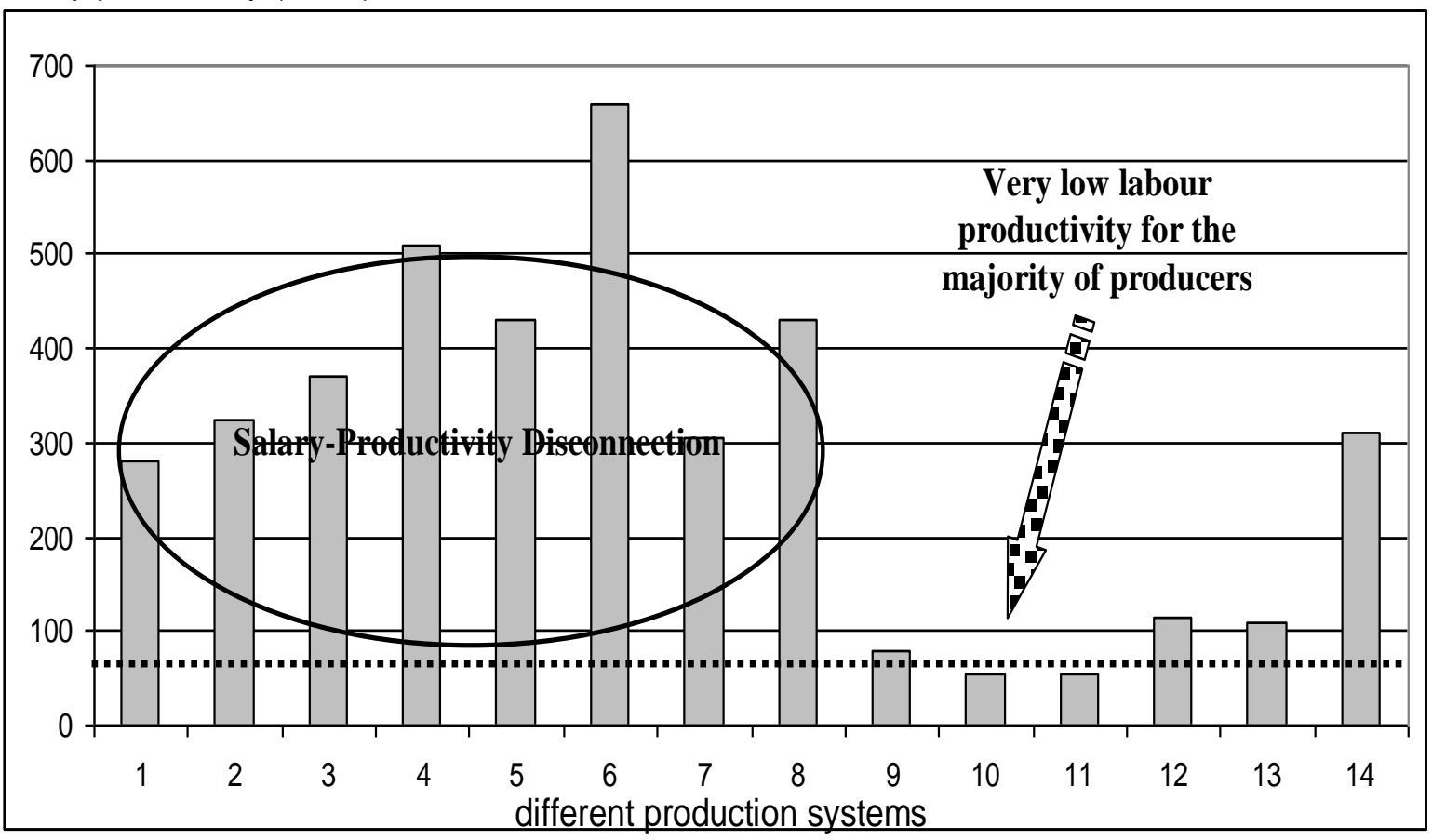

Figure 2: Daily Labour Productivity for Production Systems Studied in the Hazyview Region, Mpumalanga (Dotted line = minimum wage)

(Source: Cochet et al., 2015)

Irrespective of the high level of daily labour productivity in the best equipped production systems, labour remuneration remains comparable with the very low level of labour productivity obtained in the immense majority of small agricultural production units of the region, which are deprived of land as well as irrigation water and are under-equipped.

\section{Conclusion: From Capital-Labour Separation to Profitability: the True Driving Force behind Land-Grabbing}

The World Development Report 2008 (World Development Report 2008: Agriculture for Development) recommended that rural smallholders unable to compete in higher value production should exit agriculture, in accordance with the paradigm of modernisation which is underlain by the necessary capital/labour substitution. Here we agree with other authors who, in criticising the Report, highlight the fact that the current "agrarian transition" is of another type altogether. It does not come with a massive transfer of the labour force towards other sectors of the economy (Bernstein, 2009; Li, 2011), simply because the productivity gains recorded in these other sectors means that they are no longer in a position to absorb all those who, jobless, were expelled from the countryside. This is when a long-lasting disconnection between productivity and remuneration becomes possible.

As such, our analysis of value added distribution operated in different types of capitalist farms with a salaried workforce in Ecuador, Ethiopia, Ukraine and South Africa, shows that the current processes not only reflect a capital/labour substitution phenomenon and an increase in labour productivity, but also a modification of the distribution of value added to the benefit of capital and to the detriment of labour. This type of research work should include the other 
forms of capital/labour separation we mentioned in the second part of this article. Do the different forms of reverse tenancy, developing in many regions of the world, also reflect a decrease in the share of value added dedicated to labour remuneration? Although we do lack quantified results in this regard, insofar as these contracts most often bring together a capital contributor and a labourer devoid of it, the work relations established as a result are particularly unequal. The same applies when service companies offer "clients" a form of contract closer to integration contracts, or even new forms of social relations where farmers become farm workers on their own land (supra).

In fact, the relative decrease in the portion of value added dedicated to labour remuneration, as orchestrated by capitalist-type companies, the extremely low cost of access to land (and irrigation water), and the quasi-absence of land tax or redistributive measures, have opened up the way for creating a highly profitable capitalist agricultural sector, insofar as labour remuneration can from now on remain very much below productivity and generate important profits. Contrary to family farming which seeks both an increase in labour productivity and remuneration, the strategy adopted by land grabbing actors consists in increasing labour productivity without increasing labour remuneration. As such, in addition to the gains realised in labour productivity, profitability increases due in particular to a relative decrease in labour remuneration. The greatest portion of value added thus created can be allocated to capital remuneration, whence particularly high profit rates ${ }^{24}$ (up to $15-20$ per cent).

The example of Ukraine is clear. Despite undeniable comparative advantages in terms of plot structure and soil conditions (in the "black earth" regions), relatively low yields (a maximum of 4 to 5 tons per hectare in wheat and barley on the black soils of the central region) and climatic irregularity (early and late frosts, drought in spring, and rains in July) limit the agricultural and economic efficiency of these systems. These structures however, appear highly profitable from a financial point of view - Internal Rate of Return of 10 to 20 per cent which would explain their recent development (Cochet and Merlet, 2011). Two factors account for the high returns on investment: i) the inexpensive land, leased for $€ 12-25 / \mathrm{ha} /$ year, and ii) low wages. A tractor driver/mechanic costs his employer as little as $€ 200-300$ per month, five to six times cheaper than farm labourers in the cereal areas of Western Europe. It is therefore the distribution of value added and not the yield level that explains the profitability of these farms ${ }^{25}$.

The profitability of large production units in expansion today (i.e. the capacity of these projects to remunerate invested capitals), is not synonymous with economic and social efficiency, since the latter is understood as the capacity to produce value added, employment and income. The replacement of pre-existing production systems, relying mainly on family farming, with productive processes based on the production of a few goods with simplified techniques consuming large quantities of fertilizers, pesticides as well as fossil energy and sometimes biotechnologies, is rarely translated into a significant increase in value added created per unit area (land productivity), job numbers and income distribution. Their financial efficiency (i.e. their capacity to remunerate invested capital) is often very high. Yet, rather than relying on established economic efficiency, profitability most often comes from a distribution of value added which is highly disadvantageous to labour, from particularly advantageous

\footnotetext{
24 The capacity of the business to remunerate invested capitals is measured via the capital enrichment rate (or profit rate) and the Internal Rate of Return (IRR) (Bridier et al., 1980).

${ }^{25}$ Of course other factors influence the success of these companies, such as benefiting in particular from high agricultural prices, as was the case in 2007, 2008 and 2011. Their success also depends on the local political conditions and the capacity of investors and their managers to reduce transaction costs as far as possible.
} 
access to land and from tax exemption as offered by host countries.

\section{References}

Albaladejo Ch., X. Arnauld de Sartre and P. Gasselin, 2012. Agriculture entrepreneuriale et destruction du travail dans la pampa argentine, Les Agricultures de firmes 1. Organisations et financiarisation, Etudes rurales juillet-décembre 2012,190: 177-192, Ecole des Hautes Etudes en Sciences Sociales, Paris.

Anseeuw X., M. Boche, T. Breu, M. Giger, J. Lay, P. Messerli and K. Nolte, 2012. Transnational Land Deals for Agriculture in the Global South, Analytical Report based on the Land Matrix Database, CDE/CIRAD/GIGA, Bern/Montpellier/Hamburg.

Bernstein H., 2009: “Agrarian questions from transition to globalisation » in H. Akram-Lodhi \& C. Kay (eds), Peasants and globalisation, London Routledge, 2009, pp. 239-261.

Borras, Saturnino Jr and Franco J. C., 2012. "Global Land Grabbing and Trajectories of Agrarian Change: A Preliminary Analysis" Journal of Agrarian Change, Vol. 12 No. 1, January 2012, pp. 34-59.

Borras, Saturnino Jr, C. Kay, S. Gomez and J. Wilkinson, 2012. "Land grabbing and global capitalist accumulation: key features in Latin America", Canadian Journal of Development Studies / Revue canadienne d'études du development Vol. 33, No 4, December 2012, 402-416.

Bridier M. and S. Michailof, 1980. Guide pratique d'analyse de projets. Évaluation et choix des projets d'investissements, Paris, Economica.

Burnod P. and J.Ph. Colin (coordinators), 2012. Large Agriculture Investments and Inclusion of Small Farmers: lessons of case studies in 7 countries, Land Tenure Working Paper 23, CIRAD/FAO

Centre d'Analyse Stratégique (CAS). [Clavé M. and D. Auverlot (coord.)] 2010. Les cessions d'actifs agricoles dans les pays en développement. Diagnostic et recommandations. La documentation française. Rapports de documents $n^{\circ} 29$. Paris. (127 p.)

Cepeda D. 2009: Ces mains qui font le régime. Dynamique et performances agroéconomiques des systèmes de production bananiers en Equateur, $\mathrm{PhD}$ dissertation, Comparative Agriculture and Agricultural Development Research Unit, AgroParisTech, Paris.

Cepeda D. and H. Cochet, 2012. Agrobusiness et agriculture familiale. Le secteur de la banane-fruit d'exportation en Equateur, Revue Tiers Monde, $N^{\circ} 210$, avril-juin 2012, pp. 183-203.

CER, 2007. L'exploitation agricole flexible, Les Cahiers du CER France, mai 2007.

Cochet H., 2008. Vers une nouvelle relation entre la terre, le capital et le travail, Etudes Foncières $n^{\circ}$ 134, juillet-août 2008, pp. 10-15.

Cochet H., 2015a. Comparative Agriculture, Springer. (first édition in french, QUAE, 2011). 
Cochet H., 2015b. Controverses sur l'efficacité économique des agricultures familiales: indicateurs pour une comparaison rigoureuse avec d'autres agricultures, Revue Tiers Monde, $N^{\circ} 221$ janvier-mars 2015, pp. 9-25, Armand Colin, Paris

Cochet H., 2017: Séparation capital/travail, flexibilité et rémunération des facteurs de production: la fin de l'exploitation agricole familiale ? Economie Rurale n³57-358 /janvier 2017

Cochet H., E. Léonard and B. Tallet, 2010. Le métayage d'élevage au Mexique, Colonisation foncière et dynamique d'une institution agraire dans l'histoire contemporaine, Annales de Géographie n 676, 2010, p. 617-638.

Cochet H., Anseeuw W., Freguin-Gresh S., 2015: South Africa's Agrarian Question, Human Sciences Research Concil, Cape Town, South Africa. (358 p).

Cochet H. and M. Merlet, 2011. Land grabbing and share of the value added in agricultural processes. A new look at the distribution of land revenues, International Academic Conference 'Global Land Grabbing'6 - 8 April 2011, University of Sussex, Brighton, UK.

Colin J-Ph., 2013. Marché fonciers et concentration foncière. La configuration de « tenure inversée » (reverse tenancy), Les Cahiers du Pôle Foncier $N^{\circ}$ 3/2013, IRD (30 p.)

Cotula, L., S. Vermeulen, R. Leonard and J. Keeley, 2009, Land grab or development opportunity? Agricultural investment and international land deals in Africa. IIED, FAO, IFAD.

CSA-HLPE, 2013. Investing in smallholder Agriculture for Food Security. A report by the High Level Panel of Experts on Food Security and Nutrition of the Committee on World Food Security, Rome.

De Schutter, O. 2009. Large-scale land acquisitions and leases: A set of minimum principles and measures to address the human rights challenge. Report of the Special Rapporteur on the right to food, General Assembly, United Nations, 28 December 2009.

Deininger K., 2011. Challenges posed by the new wave of farmland investment, The Journal of Peasant Studies Vol 38, $N^{\circ}$ 2, March 2011, 217-247.

Deininger K., D. Byerlee, J. Lindsay, A. Norton, H. Selod and M. Stickler, 2011. Rising Global Interest in farmland. Can it Yield Sustainable and Equitable Benefits? The International Bank for Reconstruction and Development / The World Bank. Washington, DC, USA, (214 p).

Dufumier M. and P. Bergeret, 2002. Analyser la diversité des exploitations agricoles, Mémento de l'agronome, CIRAD - GRET, Ministère des Affaires étrangères, Paris, pp. 321344.

El Ouaamari, 2013. Paysanneries amères au berceau de l'or brun. Développement caféier et dislocation des sociétés paysannes dans le sud-ouest éthiopien, $\mathrm{PhD}$ dissertation, Comparative Agriculture and Agricultural Development Research Unit, AgroParistech, Paris. 
Fairbairn M., Fox, J.,Isakson, S.R., Levien M., Peluso N., Razavi S., Scoones I. \& Sivaramakrishnan K., 2014: Introduction: New directions in agrarian political economy, The Journal of Peasant Studies, 41:5, 653-666,

Fairhead J., L. Melissa and I. Scoones, 2012. Green Grabbing: a new appropriation of nature? The Journal of Peasant Studies, 39:2, 237-261.

FAO, 2009. From Land Grab to Win-Win: Seizing the Opportunities of International Investments in Agriculture, Economic and Social Perspective, Policy Brief 4, June 2009.

FAO, 2011. The state of the world's land and water resources for food and agriculture (SOLAW) - Managing systems at risk, FAO and Earthscan, London (285 p.).

FAO, 2014. The State of Food and Agriculture, Innovation in Family Farming, Rome (139 p.)

Fischer, G., van Velthuizen, H.T., Shah, M.M. and Nachtergaele, F.O., 2002. Global Agroecological Assessment for Agriculture in the 21st Century: Methodology and Results, IIASA/FAO Research Report, RR-02-02.

Grosso S., 2009. Les pools de culture: diversité des combinaisons financières et productives, DÉMÉTER 2010: 223-254, Club Déméter, Paris, Armand Colin.

Guibert M. 2013. Les formes associatives de production agricole en argentine et en Uruguay: entre territoire et réseau ? Etudes rurales 1/ 2013 ( $\left.{ }^{\circ} 191\right)$, p. 77-90.

Hervieu B., Purseigle F., 2009: «Pour une sociologie des mondes agricoles dans la globalisation », Etudes rurales, janvier-juin 2009, 183: 177-200.

Kautsky K., 1988. The agrarian question, London Winchester, Mass. (first published in German, 1889).

IAASTD (International Assessment of Agricultural Science Knowledge and Technology for Development) 2009. Agriculture at a Crossroad, Global Report. Edited by: Bervely D. McIntyre (IAASTD, secretariat), Hans R. Herren (Millennium Institute), Judi Wakhungu (African Centre for Technology Studies), Robert T. Watson (University of West Anglia), Island Press, Washington DC, USA.

IIASA (International Institute for Applied Systems Analysis), 2002. Global Agro-Ecological Zones Assessment, Autria.

Ioffe G., Nefedova T., 1998, Continuity \& Change in Rural Russia: A Geographical Perspective, Westview Press

Jaubertie, C. 2009. Analyse-diagnostic dans la région de Jytomyr (Ukraine), Master dissertation, Comparative Agriculture and Agricultural Development Research Unit, AgroParistech, Paris.

Lavers, T., 2012. 'Land grab' as development strategy? The political economy of agricultural investment in Ethiopia. Journal of Peasant Studies, 39 (1). pp. 105-132. 
Li T. M., 2011. "Centring labour in the land grab debate", The Journal of Peasant Studies, Vol 38, $N^{\circ}$ 2, March 2011, 281-298.

McMichael Ph., 2011. Interpreting the Land Grab, discussion paper, TNI - LDPI.

Mazoyer M. and L. Roudart, 2006. A history of world agriculture, from the Neolithic age to the current crisis (translated from French by James H. Membrez), EARTHSCAN, London. Sterling, VA (528 p.)

Meillassoux C., 1975: Femmes, greniers et capitaux, Maspero, Paris (254 p.)

OECD, 2012, "Labour Losing to Capital: What Explains the Declining Labour Share?", OECD Employment Outlook 2012, pp. 109-161.

Oya C., 2013. The Land Rush and Classic Agrarian Questions of Capital and Labour: a systematic scoping review of the socioeconomic impact of land grabs in Africa, Third World Quarterly, Vol. 34, $N^{\circ}$ 9, 2013, pp 1532-1557.

Posada M. and M. Martínez de Ibarreña, 1998. Capital financiero y producción agrícola: los pools de siembra en la región pampeana, Realidad económica 153: 112-135.

Purseigle, F., Chouquer, G., 2012: 'Les agricultures de firme - Volume 1. Organisations et financiarisation', Etudes Rurales, juillet-décembre 2012 (Numéro spécial 190), Paris.

Purseigle, F., Chouquer, G. 2013: 'Les agricultures de firme - Volume 2. Délocalisation et évictions', Etudes Rurales, janvier-juin 2013 (Numéro spécial 191), Paris.

Randimbivololona, C. and D. Sanchez, 2010. Analyse-diagnostic agro-économique du District de Znamienka, Ukraine. Master dissertation, Comparative Agriculture and Agricultural Development Research Unit, AgroParistech, Paris.

Servolin C., 1972: "L'absorption de l'agriculture dans le mode de production capitaliste", in: Tavernier Y., Gervais M. et Servolin C. (ed), 1992: L'univers politique des paysans dans le France contemporaine, cahiers de la fondation nationale des sciences politiques $\mathrm{n}^{\circ} 184$, Librairie Armand Colin et Fondation Nationale des Sciences Politiques, Paris (pp. 41-77)

Songwe, V. and K. Deininger, 2009. Foreign Investment in Agricultural Production: opportunities and Challenges. Notes, Land Policy and Administration, Agriculture and Rural Development, The World Bank, issue 45, January 2009.

Sourisseau J-M. (ed), 2014. Agricultures familiales et mondes à venir, QUAE éditions, Versailles (360 p.).

Tchayanov A., 1966. The Theorie of Peasant Economy, Homewood, Illinois, RD, Irwin (first edition in Dutch, 1923; first edition in Russian 1924).

Technical Committee on Land Tenure and Development. [Merlet, M. Perdriault M., (AGTER)], 2010. Large-scale land appropriations. Analysis of the phenomenon and proposed guidelines for future action, AFD, MAEE, Paris, June 2010. (53 p.) 
UNCTAD,2009. World Investment Report, Transnational Corporations, Agricultural Production and Development, United Nations, September 2009.

Visser, O., Mamonova, N.V. \& Spoor, M., 2012. Oligarchs, megafarms and land reserves: understanding land grabbing in Russia. Journal of Peasant Studies, 39:3-4, 899-931.

Von Braun J. and R. Meinzen-Dick, 2009. "Land Grabbing" by Foreign Investors in Developing Countries: Risks and Opportunities, IFPRI Policy Brief 13.

World Bank. 2007. World Development Report 2008: Agriculture for Development. Washington, DC. (C) World Bank. https://openknowledge.worldbank.org/handle/10986/5990 License: CC BY 3.0 IGO."

World Bank 2008. World Development Report: Agriculture for Development. Washington, DC: World Bank.

Yefimov V., 2003, Économie institutionnelle des transformations agraires en Russie, L'Harmattan, Paris, 400 p. 